\title{
By-Products Produced by the Reaction of Estrogens with Hypochlorous Acid and their Estrogen Activities
}

\author{
Hideyuki Nakamura, ${ }^{a}$ Tatsushi Shiozawa, ${ }^{a}$ Yoshiyasu Terao, ${ }^{*, a}$ Fujio Shiraishi, ${ }^{b}$ \\ and Hitoshi Fukazawa ${ }^{c}$
}

${ }^{a}$ Institute for Environmental Sciences and COE Program in the 21th Century, University of Shizuoka, 51-1 Yada, Suruga-ku, Shizuoka 422-8526, Japan, ${ }^{b}$ National Institute for Environmental Studies, 16-2 Onogawa, Tsukuba, Ibaraki 305-8506, Japan, and 'Shizuoka Institute of Environment and Hygiene, 4-27-2 Kita-ando, Aoi-ku, Shizuoka 420-8637, Japan

(Received October 25, 2005; Accepted January 5, 2006; Published online January 12, 2006)

\begin{abstract}
Estrogens that originate from humans and animals are thought of as a factor of endocrine disruptors in the environment. We investigated their halogenated derivatives, which could be produced by chlorine treatment at a sewage treatment plant. The chlorinated derivatives of estrone (E1), 17 $\beta$-estradiol (E2), estriol (E3), and 17 $\alpha$ ethynylestradiol (EE2) were produced by the reaction with hypochlorous acid in organic solvents and also brominated derivatives when bromide ions were present. The structures of chlorinated and brominated estrogens isolated were determined by MS and NMR spectroscopy. The estrogenic activities of the halogenated derivatives were measured by yeast two-hybrid assays incorporating the human estrogen receptor $\alpha(\mathrm{hER} \alpha)$ or medaka fish (Oryzias latipes) estrogen receptor $\alpha(\operatorname{medER} \alpha)$. Although the activities of 4-chloroestrone (4-ClE1) and 10-chloro-1,4estradiene-3,17-dione were similar to those of E1, the activities of 2-ClE1 and 2,4-dichloroestrone (2,4-diClE1) were approximately $4 / 5$ and 1/50 that of E1, respectively, in an agonist assay for hER $\alpha$. No activity was detected in 2,4,16,16-tetrachloroestrone (2,4,16,16-tetraClE1). The estrogenicities of chlorinated derivatives of E2, E3, and EE2 showed a similar tendency to that of E1. The brominated derivatives showed slightly weaker activity than the corresponding chlorinated derivatives. However, many estrogens halogenated at the 2 and 4 positions still had activity that was approximately $10^{3}-10^{4}$ times stronger than that of bisphenol A.
\end{abstract}

Key words — estrogen, halogenated estrogen, estrogenic activity, yeast two-hybrid assay, hypochlorous acid, bromide ion

\section{INTRODUCTION}

Estrogens produced from humans and animals are thought of as a factor of endocrine disruptors in the environment. Nakamuro et al. reported that the estrogen activities of steroidal sex hormones, such as estrone (E1), $17 \beta$-estradiol (E2), and estriol (E3), were approximately $10^{2}-10^{4}$ times stronger than those of man-made compounds that are known as endocrine disruptors. ${ }^{1)}$ However, steroidal sex hormones that are collected at a sewage treatment plant are discharged into local sources of water through the disinfecting process. Organochlorine compounds, which are produced when hypochlor-

*To whom correspondence should be addressed: Institute for Environmental Sciences, University of Shizuoka, 51-1 Yada, Suruga-ku, Shizuoka 422-8526, Japan. Tel. \& Fax: +81-54-2645788; E-mail: terao@u-shizuoka-ken.ac.jp ous acid is used as a disinfectant, are reported to have negative effects on the ecosystem. ${ }^{2-6)}$ Estrogens also can be chlorinated and oxidized with hypochlorous acid in sewage treatment plants. Therefore, the reactivity of hypochlorous acid for estrogens, the structure of the products, and the toxicities including estrogen activity need to be determined for estimation of the potential risk.

We therefore investigated in detail the reaction of E1, E2, E3, and 17 $\alpha$-ethynylestradiol (EE2) with hypochlorous acid in organic solvents.

\section{MATERIALS AND METHODS}

UV spectra were measured on a Tosoh PD-8020 photodiode array detector and Beckman DU 640 spectrophotometer. NMR spectra were taken on a JEOL JNM-GSX500 ( $\left.{ }^{1} \mathrm{H}, 500 \mathrm{MHz}:{ }^{13} \mathrm{C}, 125 \mathrm{MHz}\right)$ 
Fourier transform spectrometer with tetramethylsilane (TMS) as an internal standard. Chemical shifts are expressed in $\delta$ values. FAB-MS measurements were taken on a JEOL JMS-SX103 mass spectrometer, and $m$-nitrobenzyl alcohol was used as a matrix. Analytical high performance liquid chromatography (HPLC) was performed on a Wakopack-naviC30 column $(4.6 \times 250 \mathrm{~mm})$ with $65 \%$ acetonitrile at a flow rate of $0.8 \mathrm{ml} / \mathrm{min}$, and it was assessed with a UV-spectrophotometric detector at $254 \mathrm{~nm}$. Preparative HPLC was carried out on a YMC-pack ODS-A $(50$ or $20 \times 250 \mathrm{~mm})$ at a flow rate of $8 \mathrm{ml} / \mathrm{min}$.

Steroidal compounds were purchased from Aldrich Chem. Co., U.S.A. A sodium hypochlorite solution ( $>5 \%$ available chlorine) was purchased from Wako Pure Chemicals, Industries Ltd., Osaka, Japan. The available chlorine concentration in the solution was measured using the iodometric titration method.

\section{Reaction with Hypochlorous Acid — The re-} action of estrogens with hypochlorous acid was carried out using the following general procedure.

An aqueous solution of sodium hypochlorite ( $0.6 \mathrm{ml}, 6 \%$ available chlorine) was added to a solution of steroid $(1 \mathrm{mmol})$ in methanol $(100 \mathrm{ml})$ or acidic $80 \%$ methanol (including potassium bromide) and stirred. After $30 \mathrm{~min}$ of stirring at room temperature, an aqueous solution of sodium sulfite was added in an ice bath. The mixture was acidified with a $6 \%$ hydrochloric acid, and methanol was removed under reduced pressure. The aqueous residue was extracted with dichloromethane after adding sodium chloride. The dichloromethane solution was washed with brine and dried over sodium sulfate. After removal of the dichloromethane, the residue was dissolved in a solvent $(20 \mathrm{ml})$ used for a mobile phase of preparative HPLC. The mixture of mono- and dichlorinated derivatives separated into each component as a pure state by using methanol/water [70/30 to $80 / 20(\mathrm{v} / \mathrm{v})$ ] as the mobile phase.

Estrogenic Activity of Halogenated Derivatives of Estrogens — The agonist activities of halogenated estrogens were measured with a yeast twohybrid estrogenicity assay ${ }^{7,8)}$ using yeast cells ( $\mathrm{Sac}$ charomyces cerevisiae Y190) into which the human $(\mathrm{hER} \alpha)$ or medaka estrogen receptor $\alpha(\operatorname{medER} \alpha$ : Oryzias latipes) and coactivator TIF2 had been introduced. Expression plasmids for each hormone receptor ligand binding domain and pGAAD424TIF2 were introduced into yeast cells that carried the $\beta$-galactosidase reporter gene. Both assays were adapted to a chemiluminescent (CLN) reporter gene (for $\beta$-galactosidase) in a method using a 96-well culture plate. Agonist activity was recorded as the $\mathrm{EC}_{\times 10}$ that was defined as the concentration of the test solution producing a CLN intensity 10 times that of the blank control. The CLN intensity of each test solution was adapted to the mean of two measurements. Further details of the assay were described in a previous paper. ${ }^{3)}$

\section{RESULTS AND DISCUSSION}

\section{Reaction of Estrogens with Hypochlorous Acid}

Many kinds of chlorinated derivatives produced by the reaction of $\mathrm{E} 2$ and hypochlorous acid were detected in the previous report ${ }^{9)}$ by LC-MS/MS analysis. However, those products were not isolated, and the structures of most of them were not obvious. The isolation of pure products and the determination of their structures are required for environmental problems caused by chlorination in sewage treatment plants to be elucidated. To isolate the pure products, we carried out the reactions of E1, E2, E3, and EE2 in organic solvents and used preparative HPLC to separate them. The chemical structures of the products and the experimental results are shown in Fig. 1 and Table 1, respectively.

Because E1 was reported to be more present in the environment than E2,10) the reaction of E1 with sodium hypochlorite was first carried out in a methanol solution. Five chlorinated derivatives, 2chloroestrone (2-ClE1), 4-chloroestrone (4-ClE1), 2,4-dichloroestrone (2,4-diClE1), 2,4,16,16-tetrachloroestrone (2,4,16,16-tetraClE1), and 10-chloro1,4-estradiene-3,17-dione (10-Cl-1,4-estradiene-3,7dione) were isolated.

The production of 10-Cl-1,4-estradiene-3,7dione is considered to be produced by oxidation of the 3-hydroxy group with hypochlorous acid to a corresponding quinone. A further chlorination of active methylene at the 16 position leads to being formed. A small amount of 4-chloro-2-methoxyestrone (4-Cl-2-MeOE1) seems to be formed by substituting chlorine with a methoxy group.

The reactions of E2, E3, and EE2 with hypochlorous acid under similar conditions afforded the corresponding mono- and di-chlorinated derivatives, which were isolated in a pure state. E1 and its chlorinated derivatives were obtained in the reaction with E2 because a hydroxy group at the 17 position was oxidized with hypochlorous acid. 
<smiles>[R]c1cc2c(c([R2])c1O)CCC1C2CC[C@]2(C)C(=O)C([R4])([R3])CC12</smiles>

Estrone (E1)

E1: $R_{1}=H, R_{2}=H, R_{3}=H, R_{4}=H$ 2-CIE1 \& 2-BrE1: $R_{1}=X, R_{2}=H, R_{3}=H, R_{4}=H$ 4-CIE1 \& 4-BrE1: $\mathrm{R}_{1}=\mathrm{H}, \mathrm{R}_{2}=\mathrm{X}, \mathrm{R}_{3}=\mathrm{H}, \mathrm{R}_{4}=\mathrm{H}$ 2,4-diCIE1 \& 2,4-diBrE1: $\mathbf{R}_{1}=\mathbf{X}, \mathrm{R}_{2}=\mathbf{X}, \mathrm{R}_{3}=\mathrm{H}, \mathrm{R}_{4}=\mathrm{H}$ 2,4,16,16-tetraClE1: $\mathrm{R}_{1}=\mathrm{Cl}, \mathrm{R}_{2}=\mathrm{Cl}, \mathrm{R}_{3}=\mathrm{Cl}, \mathrm{R}_{4}=\mathrm{Cl}$ 4-Cl-2-methoxyE1: $\mathrm{R}_{1}=\mathrm{CH}_{3} \mathrm{O}, \mathrm{R}_{2}=\mathrm{Cl}, \mathrm{R}_{3}=\mathrm{H}, \mathrm{R}_{4}=\mathrm{H}$<smiles>[R9]c1cc2c(c([R10])c1O)CCC1C2CC[C@@]2(C)[C@H]1CC[C@]2(O)C#C</smiles>

17 $\alpha$-Ethynylestradiol (EE2)<smiles>[R5]c1cc2c(c([R6])c1O)CCC1C2CC[C@]2(C)[C@H]1CC[C@H]2O</smiles>

17ß-Estradiol (E2)

$E 2: R_{5}=H, R_{6}=H$

2-CIE2 \& 2-BrE2: $\mathrm{R}_{5}=\mathrm{X}, \mathrm{R}_{6}=\mathrm{H}$

4-CIE2 \& 4-BrE2: $R_{5}=H, R_{6}=X$

2,4-diCIE2 \& 2,4-diBrE2: $R_{5}=X, R_{6}=X$<smiles>[R]c1cc2c(c([R5])c1O)CCC1C2CC[C@@]2(C)[C@H]1C[C@H](O)[C@H]2O</smiles>

Estriol (E3)

E3: $\mathbf{R}_{7}=\mathbf{H}, \mathbf{R}_{8}=\mathbf{H}$

2-CIE3 \& 2-BrE3: $\mathrm{R}_{7}=\mathrm{X}, \mathrm{R}_{\mathbf{8}}=\mathrm{H}$

4-CIE3 \& 4-BrE3: $\mathrm{R}_{7}=\mathrm{H}, \mathrm{R}_{8}=\mathrm{X}$

2,4-diCIE3 \& 2,4-diBrE3: $R_{7}=X, R_{8}=X$

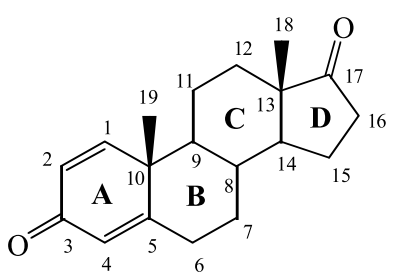

1,4-androstadiene-3,17-dione<smiles>C[C@]12CCC3C(CCC4=CC(=O)C=CC43Cl)C1CCC2=O</smiles>

10-Cl-1,4-estradiene-3,17-dione (10-ClEsra)

EE2: $\mathbf{R}_{9}=\mathrm{H}, \mathrm{R}_{10}=\mathrm{H}$

2-CIEE2 \& 2-BrEE2: $\mathrm{R}_{9}=\mathrm{X}, \mathrm{R}_{10}=\mathrm{H}$

4-CIEE2 \& 4-BrEE2: $R_{9}=H, R_{10}=X$

2,4-diCIEE2 \& 2,4-diBrEE2: $R_{9}=X, R_{10}=X$

Fig. 1. Chemical Structures of E1, E2, E3, EE2, and their Halogenated Derivatives

$\mathrm{X}=\mathrm{Cl}$ or $\mathrm{Br}$

Table 1. Reaction of Steroids with Hypochlorous Acid

\begin{tabular}{|c|c|c|}
\hline Substrate & Solvent & Isolated compounds (yield, \%) \\
\hline E1 & $\mathrm{MeOH}$ & $\begin{array}{l}\text { E1 (6.9), 2-ClE1 (1.6), 4-ClE1 (12.2), diClE1 (4.4), 10-ClEstra (7.7), tetraClE1 (2.5), } \\
\text { 4-Cl-2-MeOE1 (1.2) }\end{array}$ \\
\hline E2 & $\mathrm{MeOH}$ & $\begin{array}{l}\mathrm{E} 2 \text { (19.5), 2-ClE2 (0.9), 4-ClE2 (5.2), diClE2 (7.5), E1 (0.1), 2-ClE1 (1.7), 4-ClE1 (1.5), } \\
\text { diClE1 (0.02) }\end{array}$ \\
\hline E3 & $\mathrm{MeOH}$ & E3 (20.7), 2-ClE3 (3.4), 4-ClE3 (9.9), diClE3 (9.9) \\
\hline EE2 & $\mathrm{MeOH}$ & EE2 (19.2), 2-ClEE2 (1.7), 4-ClEE2 (5.8), diClEE2 (4.8) \\
\hline E1 & $80 \% \mathrm{MeOH}^{a)}$ & E1 (1.5), 2-BrE1 (1.7), 4-BrE1 (2.6), diBrE1 (3.7) \\
\hline E2 & $80 \% \mathrm{MeOH}^{a)}$ & E2 (3.5), 2-BrE2 (16.1), 4-BrE2 (22.2), diBrE2 (16.7) \\
\hline E3 & $80 \% \mathrm{MeOH}^{a)}$ & E3 (1.2), 2-BrE3 (7.0), 4-BrE3 (6.4), diBrE3 (2.7) \\
\hline EE2 & $80 \% \mathrm{MeOH}^{a)}$ & EE2 (0.4), 2-BrEE2 (20.6), 4-BrEE2 (41.1), diBrEE2 (12.9) \\
\hline
\end{tabular}

a) In the presence of $\mathrm{KBr}$.

\section{Determination of the Structures of Halogenated Estrogens}

The structures of the products, 2-ClE1, 4-ClE1, and 2,4-diClE1 were determined by FAB-MS and NMR spectroscopy. The ${ }^{1} \mathrm{H}-\mathrm{NMR}$ spectrum of 4ClE1, a typical halogenated estrogen, is depicted in Fig. 2. The FAB-MS and ${ }^{1} \mathrm{H}-\mathrm{NMR}$ spectral data for all halogenated compounds are summarized in Table 2. The ${ }^{13} \mathrm{C}$-NMR spectral data for chlorinated derivatives of $\mathrm{E} 1$ are shown in Table 3.

In the FAB-MS spectra, each compound shows a parent peak at a mass number corresponding to $\mathrm{M}^{+}$, including the peaks of chlorine isotopes. In the ${ }^{1} \mathrm{H}-\mathrm{NMR}$ spectra, the regions of aromatic protons 


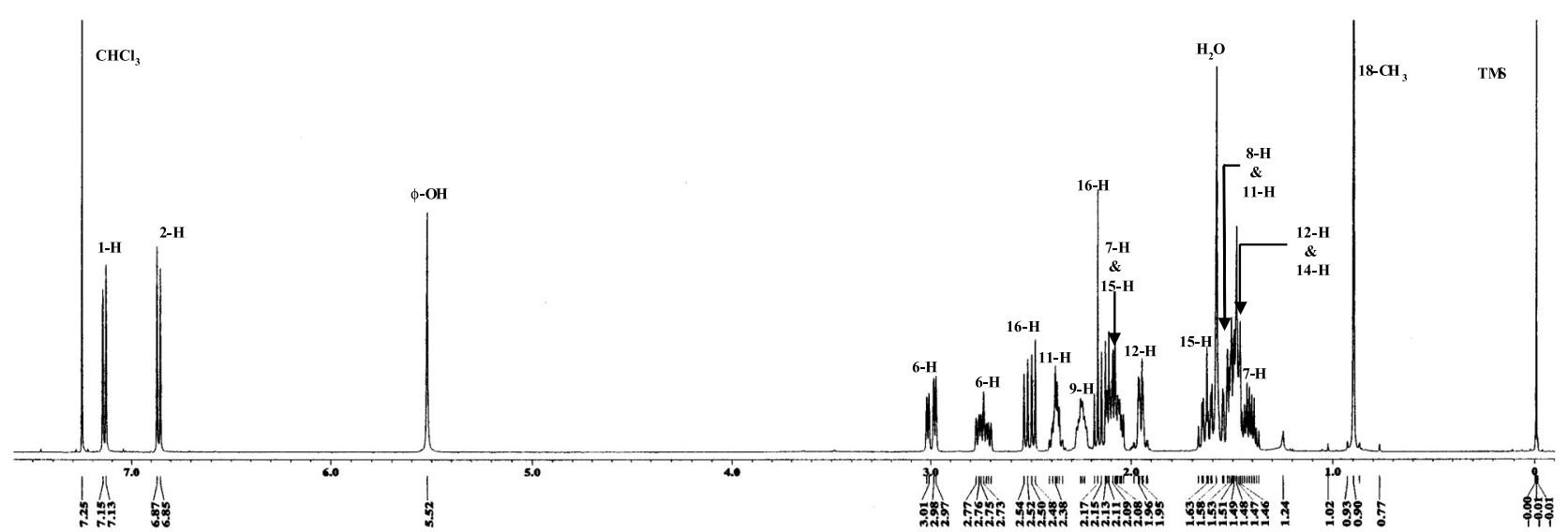

Fig. 2. ${ }^{1} \mathrm{H}-\mathrm{NMR}$ Spectrum of $4-\mathrm{ClE} 1$ as a Typical Halogenated Estrogen

show two singlet peaks (7.20 and $6.74 \mathrm{ppm}$ ) for 2ClE1, two doublet peaks $[7.14(J=8.6 \mathrm{~Hz})$ and $6.86 \mathrm{ppm}(J=8.6 \mathrm{~Hz})]$ for 4-ClE1, and a singlet peak (7.20 ppm) for 2,4-diClE1. The peaks for the other steroid skeleton exhibit a similar pattern to those of E1. The ${ }^{13} \mathrm{C}$-NMR spectra are also consistent with their structures.

The structure of 10-Cl-1,4-estradiene-3,7-dione was determined as follows. This compound was identified as a mono-chlorinated derivative by FABMS spectroscopy, where the relative isotopic abundance of chlorine in the parent peak is $m / z, 304: 306$ $=3: 1$. The ${ }^{1} \mathrm{H}-\mathrm{NMR}$ spectrum shows an $\mathrm{ABX}$ spin coupled system in a low magnetic field: $7.10 \mathrm{ppm}$ $\left({ }^{1} \mathrm{H}, \mathrm{d}, J=10.3 \mathrm{~Hz}\right), 6.18 \mathrm{ppm}\left({ }^{1} \mathrm{H}, \mathrm{dd}, J=10.3\right.$, $1.7 \mathrm{~Hz})$, and $6.06 \mathrm{ppm}\left({ }^{1} \mathrm{H}, \mathrm{d}, J=1.7 \mathrm{~Hz}\right)$, which suggest that the A-ring is not an aromatic ring system. The UV spectrum also displays an absorption maximum at $238 \mathrm{~nm}$ - a shorter wavelength in comparison with that of an aromatic compound. A comparison of the ${ }^{1} \mathrm{H}-\mathrm{NMR}$ spectrum with that of an authentic 1,4-androstadiene-3,17-dione revealed that both spectra are similar except for a signal caused by methyl at the 10 position of an authentic sample. In the ${ }^{13} \mathrm{C}-\mathrm{NMR}$ spectrum, a peak at $67.59 \mathrm{ppm}$ assigned to C-10 shifts to the lower field by $24.10 \mathrm{ppm}$ than the peak (43.49 ppm) assigned to C-10 of 1,4androstene-3,17-dione, owing to chlorine substitution. These data support that this compound is 10Cl-1,4-estradiene-3,17-dione formed by the oxidation with hypochlorous acid.

The FAB-MS spectrum of 2,4,16,16-tetraClE1 shows a parent peak at $\mathrm{m} / \mathrm{z} 406$ with a relative isotopic abundance of chlorine: $\mathrm{m} / \mathrm{z} 406: 408: 410: 412$ $: 414=18: 23: 12: 3: 1$, indicating that it is tetra- chlorinated estrone. The singlet peak at $7.19 \mathrm{ppm}$ in the ${ }^{1} \mathrm{H}-\mathrm{NMR}$ spectrum reveals that two chlorines were substituted at the 2 and 4 positions. In the ${ }^{13} \mathrm{C}$ NMR spectrum, a peak at $82.81 \mathrm{ppm}$ appears as an obvious result of a low-field shift of a peak at $35.97 \mathrm{ppm}$ due to methylene carbon at the 16 position of estrone, owing to the substitution of two chlorines. A peak due to the methyl group of estrone also shifts to the low field in the spectrum of this compound owing to the influence of two chlorines at $\mathrm{C}-16$.

The data of the distortionless enhancement by polarization transfer (DEPT), ${ }^{1} \mathrm{H}-{ }^{1} \mathrm{H}$ correlation spectroscopy $\left({ }^{1} \mathrm{H}-{ }^{1} \mathrm{H}\right.$ cosy), the heteronuclear multiplequantum correlation (HMQC), and the heteronuclear multiple-bond correlation (HMBC) spectra were also consistent with the structure of each of the chlorinated compounds described above. The structures of chlorinated E2, E3, and EE2 were determined using a similar spectroscopic method to the E1 derivatives.

\section{Reaction of Estrogens with Hypochlorous Acid in the Presence of Bromide Ions}

Organobromine compounds were observed to form when the reaction with hypochlorous acid was carried out in the presence of bromide ions. We detected 2,4,6-tribromophenol, not 2,4,6-trichlorophenol, in an actual effluent from a sewage treatment plant near the sea. ${ }^{11)}$ Sea water including bromide ions was found to be introduced into the disinfection process of the plants. Therefore, formation of organobromine compounds and their toxicities are also not negligible for environmental pollution. On the basis of this point of view, we started the reac- 
Table 2. ${ }^{1} \mathrm{H}-\mathrm{NMR}(500 \mathrm{MHz})$ and FAB-MS Date for Estrogens and their Halogenated Derivatives

\begin{tabular}{|c|c|c|c|c|}
\hline \multirow{3}{*}{ Compound } & \multirow{3}{*}{ FAB-MS $(m / z)$} & \multicolumn{3}{|c|}{${ }^{1} \mathrm{H}-\mathrm{NMR}\left(\mathrm{CDCl}_{3}\right)^{a)}$} \\
\hline & & \multicolumn{3}{|c|}{ Position } \\
\hline & & 1 & 2 & 4 \\
\hline E1 & $270\left(\mathrm{M}^{+}\right)$ & $7.15 \mathrm{~d} \quad(8.6)$ & $6.64 \mathrm{dd}(2.9,8.6)$ & $6.58 \mathrm{~d}(2.9)$ \\
\hline 2-ClE1 & $304,306\left(\mathrm{M}^{+}\right)$ & $7.20 \mathrm{~s}$ & & $6.74 \mathrm{~s}$ \\
\hline 4-ClE1 & $304,306\left(\mathrm{M}^{+}\right)$ & $7.14 \mathrm{~d} \quad(8.59)$ & & $6.86 \mathrm{~d}(8.59)$ \\
\hline 2,4-diClE1 & $338,340,342\left(\mathrm{M}^{+}\right)$ & $7.20 \mathrm{~s}$ & & \\
\hline tetraClE1 & $406,408,410,412,414\left(\mathrm{M}^{+}\right)$ & $7.19 \mathrm{~s}$ & & \\
\hline 2-BrE1 & $348,350\left(\mathrm{M}^{+}\right)$ & $7.33 \mathrm{~s}$ & & $6.74 \mathrm{~s}$ \\
\hline 4-BrE1 & $348,350\left(\mathrm{M}^{+}\right)$ & $7.18 \mathrm{~d} \quad(8.59)$ & $6.86 \mathrm{~d} \quad(8.59)$ & \\
\hline 2,4-diBrE1 & $426,428,430\left(\mathrm{M}^{+}\right)$ & $7.40 \mathrm{~s}$ & & \\
\hline 1,4-androstadiene & $284\left(\mathrm{M}^{+}\right)$ & $7.02 \mathrm{~d}(10.3)$ & $6.20 \mathrm{dd}(1.7,10.3)$ & $6.05 \mathrm{~d}(1.7)$ \\
\hline 10-Cl-1,4-estradiene & $305,307\left(\mathrm{MH}^{+}\right)$ & $7.10 \mathrm{~d}(10.3)$ & $6.18 \mathrm{dd}(1.7,10.3)$ & $6.06 \mathrm{~d}(1.7)$ \\
\hline 4-Cl-2-methoxyE1 & $334,336\left(\mathrm{M}^{+}\right)$ & $6.88 \mathrm{~s}$ & & \\
\hline E2 & $272\left(\mathrm{M}^{+}\right)$ & $7.15 \mathrm{~d} \quad(8.6)$ & $6.62 \mathrm{dd}(2.9,8.6)$ & $6.55 \mathrm{~d}(2.3)$ \\
\hline 2-ClE2 & $306,308\left(\mathrm{M}^{+}\right)$ & $7.19 \mathrm{~s}$ & & $6.72 \mathrm{~s}$ \\
\hline 4-ClE2 & $306,308\left(\mathrm{M}^{+}\right)$ & $7.14 \mathrm{~d} \quad(8.6)$ & $6.85 \mathrm{~d} \quad(8.6)$ & \\
\hline 2,4-diClE2 & $340,342,344\left(\mathrm{M}^{+}\right)$ & $7.20 \mathrm{~s}$ & & \\
\hline $2-\mathrm{BrE} 2^{b)}$ & $350,352\left(\mathrm{M}^{+}\right)$ & $7.27 \mathrm{~s}$ & & $6.56 \mathrm{~s}$ \\
\hline $4-\mathrm{BrE} 2^{b)}$ & $350,352\left(\mathrm{M}^{+}\right)$ & $7.09 \mathrm{dd}(8.4)$ & $6.68 \mathrm{dd}(8.4)$ & \\
\hline 2,4-diBrE $2^{b)}$ & $428,430,432\left(\mathrm{M}^{+}\right)$ & $7.35 \mathrm{~s}$ & & \\
\hline E3 & $288\left(\mathrm{M}^{+}\right)$ & $7.05 \mathrm{~d} \quad(8.6)$ & $6.51 \mathrm{dd}(2.3,8.6)$ & $6.45 \mathrm{~d}(2.3)$ \\
\hline 2-ClE3 & $322,324\left(\mathrm{M}^{+}\right)$ & $7.11 \mathrm{~s}$ & & $6.57 \mathrm{~s}$ \\
\hline 4-ClE3 & $322,324\left(\mathrm{M}^{+}\right)$ & $7.06 \mathrm{~d} \quad(8.6)$ & $6.70 \mathrm{~d} \quad(8.6)$ & \\
\hline 2,4-diClE3 & $356,358,360\left(\mathrm{M}^{+}\right)$ & $7.15 \mathrm{~s}$ & & \\
\hline $2-\mathrm{BrE}^{b)}$ & $366,368\left(\mathrm{M}^{+}\right)$ & $7.27 \mathrm{~s}$ & & $6.57 \mathrm{~s}$ \\
\hline $4-\mathrm{BrE} 3^{b)}$ & $366,368\left(\mathrm{M}^{+}\right)$ & 7.09 dd (8.4) & $6.69 \mathrm{dd}(8.4)$ & \\
\hline 2,4-diBrE $3^{b)}$ & $444,446,448\left(\mathrm{M}^{+}\right)$ & $7.38 \mathrm{~s}$ & & \\
\hline EE2 & $296\left(\mathrm{M}^{+}\right)$ & $7.16 \mathrm{~d} \quad(8.6)$ & $6.63 \mathrm{dd}(2.3,8.6)$ & $6.56 \mathrm{~d}(2.3)$ \\
\hline 2-ClEE2 & $330,332\left(\mathrm{M}^{+}\right)$ & $7.20 \mathrm{~s}$ & & $6.73 \mathrm{~s}$ \\
\hline 4-ClEE2 & $330,332\left(\mathrm{M}^{+}\right)$ & $7.15 \mathrm{~d} \quad(8.6)$ & $6.85 \mathrm{~d} \quad(8.6)$ & \\
\hline 2,4-diClEE2 & $364,366,368\left(\mathrm{M}^{+}\right)$ & $7.21 \mathrm{~s}$ & & \\
\hline 2-BrEE2 & $374,376\left(\mathrm{M}^{+}\right)$ & $7.25 \mathrm{~s}$ & & $6.73 \mathrm{~s}$ \\
\hline 4-BrEE2 & $374,376\left(\mathrm{M}^{+}\right)$ & $7.19 \mathrm{dd}(8.4)$ & $6.85 \mathrm{dd}(8.4)$ & \\
\hline 2,4-diBrEE2 & $452,454,456\left(\mathrm{M}^{+}\right)$ & $7.40 \mathrm{~s}$ & & \\
\hline
\end{tabular}

a) Chemical shifts are $\delta$ values and followed by multiplicit ( $\mathrm{s}=$ singlet, $\mathrm{d}=$ doublet, $\mathrm{dd}=$ doublet of doublets) and $J \mathrm{values}(\mathrm{Hz}) . b$ )

${ }^{1} \mathrm{H}-\mathrm{NMR}$ spectrum was measured in methanol- $d_{4}$.

tions of E1, E2, E3, and EE2 with hypochlorous acid in acidic $80 \%$ methanol in the presence of potassium bromide.

Brominations of the estrogens were revealed to take place rapidly under these conditions. Although HPLC did not detect many chlorinated derivatives, three kinds of corresponding brominated estrogens shown in Table 1 were isolated from every reaction mixture.

The structures of the brominated derivatives were determined by referring to MS and NMR spectra of the corresponding chlorinated derivatives (Table 2).

\section{Estrogenic Activities of Halogenated E1, E2, E3, and EE2 in Yeast Two-Hybrid Assay}

The agonist activities of chlorinated and brominated derivatives of E1, E2, E3, and EE2 were measured by means of a yeast two-hybrid estrogenicity assay using yeast cells (Y190) into which the hER $\alpha$ or medER $\alpha$ had been introduced.

The dose-response curves for the chlorinated derivatives of E1 are shown in Fig. 3. The estrogenic activities, $\mathrm{EC}_{\times 10}$ (with $\mathrm{hER} \alpha$ ) of E1, 2-ClE1, 4-ClE1, 2,4-diClE1, and 2,4,16,16-tetraClE1 were 0.50, 0.74, $0.52,24 \mathrm{nM}$, and not detected, respectively. Although the activity of 4-ClE1 was similar to that of E1, the 
Table 3. ${ }^{13} \mathrm{C}$-NMR $\left(\delta, \mathrm{CDCl}_{3}\right)$ Data for Chlorinated Derivatives of Estrone

\begin{tabular}{|c|c|c|c|c|c|c|c|}
\hline \multirow[t]{2}{*}{ Position } & \multicolumn{7}{|c|}{ Compound } \\
\hline & 2-ClE1 & 4-ClE1 & 2,4-diClE1 & tetraClE1 & 1,4-androstadiene & 10-Cl-1,4-estradiene & 4-Cl-2-methoxyE1 \\
\hline 1 & 125.83 & 124.75 & 124.84 & 124.61 & 155.35 & 147.53 & 111.18 \\
\hline 2 & 117.29 & 113.05 & 117.96 & 118.07 & 127.78 & 126.96 & 141.5 \\
\hline 3 & 149.15 & 149.42 & 145.75 & 145.89 & 186.24 & 184.97 & 147.27 \\
\hline 4 & 116.11 & 120.29 & 121.2 & 121.18 & 124.2 & 124.17 & 126.96 \\
\hline 5 & 137.17 & 134.8 & 134.2 & 133.77 & 168.35 & 160.52 & 137.71 \\
\hline 6 & 29.08 & 27.96 & 27.77 & 27.44 & 32.61 & 32.14 & 27.17 \\
\hline 7 & 26 & 26.15 & 26.1 & 26.1 & 32.37 & 31.51 & 26.06 \\
\hline 8 & 38.11 & 37.62 & 37.44 & 36.2 & 35.18 & 35.61 & 37.51 \\
\hline 9 & 43.87 & 44.14 & 43.93 & 43.61 & 52.37 & 53.34 & 44.44 \\
\hline 10 & 133.41 & 133.48 & 133.98 & 133.07 & 43.49 & 67.59 & 127.14 \\
\hline 11 & 26.42 & 26.33 & 26.18 & 25.49 & 22.17 & 22.55 & 26.45 \\
\hline 12 & 31.53 & 31.58 & 31.46 & 32.2 & 31.27 & 30.75 & 31.59 \\
\hline 13 & 48.03 & 47.97 & 47.89 & 47.17 & 47.75 & 47.7 & 47.92 \\
\hline 14 & 50.42 & 50.35 & 50.31 & 45.55 & 50.5 & 49.8 & 50.49 \\
\hline 15 & 21.65 & 21.64 & 21.61 & 45.74 & 21.99 & 21.97 & 21.63 \\
\hline 16 & 35.93 & 35.95 & 35.91 & 82.81 & 35.7 & 35.68 & 35.95 \\
\hline 17 & 220.82 & 220.82 & 220.56 & 205.27 & 219.95 & 219.86 & 220.74 \\
\hline 18 & 13.91 & 13.89 & 13.84 & 15.68 & 13.89 & 13.83 & 13.86 \\
\hline 19 & & & & & 18.8 & & \\
\hline $\mathrm{CH}_{3} \mathrm{O}$ & & & & & & & 60.99 \\
\hline
\end{tabular}
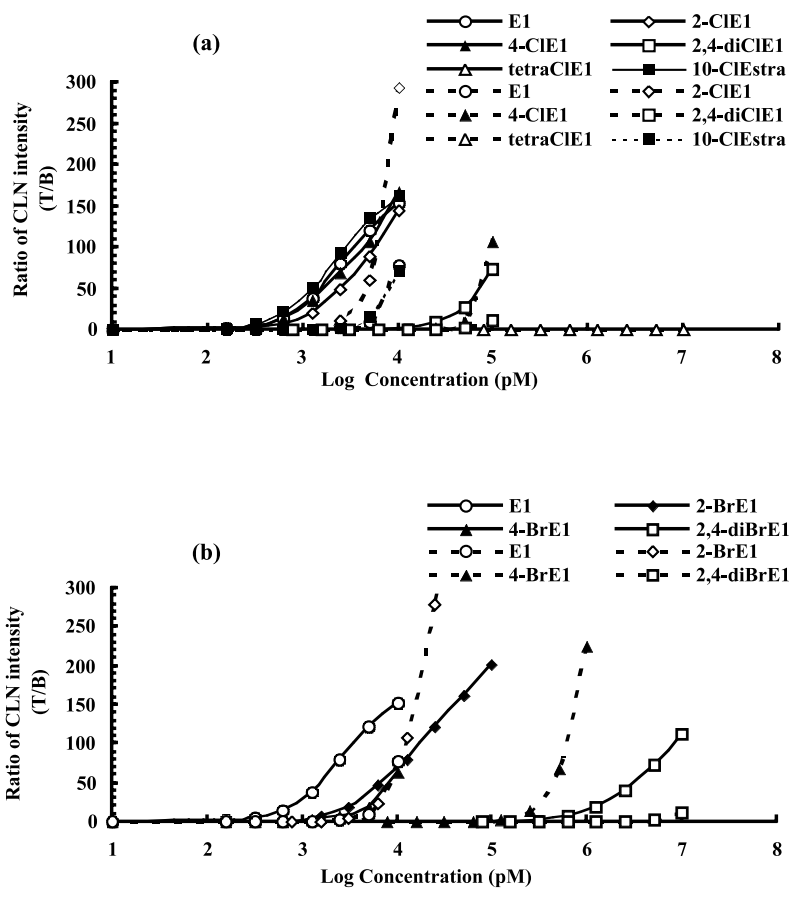

Fig. 3. Dose-Response Curves for Chlorinated E1 (a) and Brominated E1 (b) Using the Agonist (-S9) Test for the Yeast Two-Hybrid Assay with hER $\alpha$ (Full Lines) and medER $\alpha$ (Dashed Lines)

The values are represented as the ratio of CLN intensity (T/B) of $\beta$ galactosidase. activities of 2-ClE1 and 2,4-diClE1 were approximately $4 / 5$ and $1 / 50$ that of E1. Furthermore, no activity was detected in 2,4,16,16-tetraClE1 with two chlorines substituted at $\mathrm{C}-16$. These results support the idea that the estrogenic activity of E1 is influenced by a chlorine substituted at the 2 and 4 positions on A-ring and by the number of chlorines substituted.

It is of interest that the activity of 10-Cl-1,4estradiene-3,7-dione produced by oxidation of the A-ring with chlorination at $\mathrm{C}-10$ was approximately 1.4 times stronger than that of E1. In order to clarify the effect of a steroidal skeleton on estrogenicity, we measured the activity of 1,4-androstadiene-3,17dione under the same conditions. However, no estrogenicity was detected. A chlorine substituted at C-10 seems to play a important role in the estrogenic activity of 10-Cl-1,4-estradiene-3,7-dione. Dechlorination at the 10 position followed by protonation of the carbonyl group could aromatize the A-ring, resulting in E1 under the conditions.

The estrogenicities of chlorinated derivatives of E2, E3, and EE2 showed a similar tendency to those of E1. Although brominated derivatives showed slightly weaker activity than the corresponding chlorinated derivatives, the effect of bromine substitution at the 2 and 4 positions on the estrogenic activi- 
Table 4. Estrogen-Agonist Activities of Halogenated Derivatives Using the Yeast Two-Hybrid System (hER $\alpha$ and medER $\alpha$ )

\begin{tabular}{|c|c|c|c|c|c|}
\hline \multirow[t]{2}{*}{ Compound } & \multicolumn{3}{|c|}{ hER $\alpha$ Assay (-S9) } & \multicolumn{2}{|c|}{ medER $\alpha$ Assay $(-\mathrm{S} 9)$} \\
\hline & $\begin{array}{l}\text { Concentration } \\
\left.\text { range }(\mathrm{pM})^{a}\right)\end{array}$ & $\begin{array}{c}\mathrm{EC}_{\times 10^{b}}{ }^{b} \\
\mathrm{nM}\end{array}$ & $\begin{array}{c}\text { Relative activity } \\
\text { BPA }=1\end{array}$ & $\begin{array}{l}\text { Concentration } \\
\text { range }(\mathrm{pM})^{a)}\end{array}$ & $\begin{array}{c}\mathrm{EC}_{\times 10^{b}} \\
\mathrm{nM}\end{array}$ \\
\hline E1 & $0-10$ & 0.5 & $8.4 \times 10^{3}$ & $0-10$ & 4.1 \\
\hline 2-ClE1 & $0-10$ & 0.74 & $5.7 \times 10^{3}$ & $0-10$ & 2.1 \\
\hline 4-ClE1 & $0-10$ & 0.52 & $8.1 \times 10^{3}$ & $0-10^{2}$ & 40 \\
\hline 2,4-diClE1 & $0-100$ & 24 & $1.8 \times 10^{2}$ & $0-10^{2}$ & 90 \\
\hline 2,4,16,16-tetraClE1 & $0-10^{4}$ & $<10^{4}$ & $\mathrm{ND}^{c)}$ & $0-10^{4}$ & $<10^{4}$ \\
\hline 1,4-androstadiene & $0-10^{4}$ & $<10^{4}$ & $\mathrm{ND}^{c)}$ & $0-10^{4}$ & $<10^{4}$ \\
\hline 10-Cl-1,4-estradiene & $0-10$ & 0.36 & $1.2 \times 10^{4}$ & $0-10$ & 3.7 \\
\hline 2-BrE1 & $0-10^{2}$ & 2.0 & $2.1 \times 10^{3}$ & $0-10^{2}$ & 3.7 \\
\hline 4-BrE1 & $0-10$ & 3.0 & $1.4 \times 10^{3}$ & $0-10^{3}$ & $2.0 \times 10^{2}$ \\
\hline 2,4-diBrE1 & $0-10^{4}$ & $8 \times 10^{2}$ & 5.0 & $0-10^{4}$ & $9.2 \times 10^{3}$ \\
\hline E2 & $0-5$ & 0.17 & & $0-5$ & 0.56 \\
\hline 2-ClE2 & $0-10$ & 0.34 & & $0-10$ & 0.62 \\
\hline 4-ClE2 & $0-10$ & 0.16 & & $0-10$ & 1.2 \\
\hline 2,4-diClE2 & $0-10^{2}$ & 15 & & $0-10^{2}$ & 24 \\
\hline 2-BrE2 & $0-10^{2}$ & 1.2 & & $0-10^{2}$ & 1.9 \\
\hline 4-BrE2 & $0-10^{2}$ & 1.1 & & $0-10^{2}$ & 5.8 \\
\hline 2,4-diBrE2 & $0-10^{3}$ & $5 \times 10^{2}$ & & $0-10^{3}$ & $5.8 \times 10^{2}$ \\
\hline E3 & $0-10^{3}$ & 40 & & $0-10^{3}$ & $2.2 \times 10^{2}$ \\
\hline 2-ClE3 & $0-10^{3}$ & $1.4 \times 10^{2}$ & & $0-10^{3}$ & $4.2 \times 10^{2}$ \\
\hline 4-ClE3 & $0-10^{3}$ & 29 & & $0-10^{3}$ & $3.7 \times 10^{2}$ \\
\hline 2,4-diClE3 & $0-10^{4}$ & $1.6 \times 10^{3}$ & & $0-10^{4}$ & $4.9 \times 10^{3}$ \\
\hline 2-BrE3 & $0-10^{4}$ & $3.4 \times 10^{2}$ & & $0-10^{4}$ & $7.0 \times 10^{2}$ \\
\hline 4-BrE3 & $0-10^{3}$ & 72 & & $0-10^{3}$ & $1.3 \times 10^{2}$ \\
\hline 2,4-diBrE3 & $0-10^{4}$ & $<10^{4}$ & & $0-10^{4}$ & $\mathrm{ND}^{c)}$ \\
\hline EE2 & $0-10$ & 0.14 & & $0-10$ & 0.42 \\
\hline 2-ClEE2 & $0-10$ & 0.38 & & $0-10$ & 0.68 \\
\hline 4-ClEE2 & $0-10$ & 0.43 & & $0-10$ & 3.3 \\
\hline 2,4-diClEE2 & $0-10^{2}$ & 36 & & $0-10^{2}$ & 47 \\
\hline 2-BrEE2 & $0-10$ & 0.73 & & $0-10$ & 1.3 \\
\hline 4-BrEE2 & $0-10^{2}$ & 7.1 & & $0-10^{2}$ & 69 \\
\hline 2,4-diBrEE2 & $0-10^{4}$ & $6.3 \times 10^{3}$ & & $0-10^{4}$ & $5.4 \times 10^{3}$ \\
\hline
\end{tabular}

a) Concentration ranges prepared for evaluation of $\left.\mathrm{EC}_{\times 10} . b\right) \mathrm{EC}_{\times 10}$ was defined as the concentration at which the ratio of the chemiluminescent signal of the sample to that of a blank control was 10. $c$ ) ND: not detected.

ties also had a similar tendency to those of chlorinated derivatives.

Serious differences in the sensitivity were not observed between human and medaka estrogen receptors. However, it is of interest that in the yeast with medER $\alpha$, estrogens halogenated at the 2 position showed stronger activities than those at the 4 position except halogenated E3. When with $\mathrm{hER} \alpha$ the derivatives halogenated at the 4 position showed stronger activities.

Fukazawa et al. reported that bisphenol A (BPA) and its chlorinated derivatives were detected in the effluent from several pulping processes for waste paper containing thermal paper and/or other printed paper. ${ }^{3)}$ Also, chlorination enhanced the activity using the same assay system as the one in this study. A summary of the comparison of the estrogenic activities (with hER $\alpha$ ) of BPA is in Table 4. The estrogenic activities of chlorinated estrogens are entirely stronger than those of BPA. The mono-chlorinated derivatives of E1, E2, and EE2 show approximately $10^{3}-10^{4}$ times stronger activity. Even di-chlorinated derivatives are approximately 150-250 times stronger. The brominated estrogen also shows stronger estrogenic activity than BPA.

Thus, the hypochlorous acid was revealed to react easily with estrogens to create the chlorinated derivatives and brominated derivatives when in the 
presence of bromide ions. The halogenation of estrogens at the 2 and 4 positions tends to decrease the estrogenic activity. In particular, the di-chlorinated derivatives result in weak activity. It is assumed to be due to disruption in the interaction of the 3hydroxyl group with the receptor. Because we have already detected chlorinated derivatives of E1 in the effluent from one sewage treatment plant (data not shown), we have to investigate the features of halogenated derivatives for biodegradation and accumulation in the body. We also need to assess not only the estrogenic activity but also the other bioactivities in them.

\section{REFERENCES}

1) Nakamuro, K., Ueno, H., Okuno, T., Sakazaki, H., Kawai, H., Kamei, T. and Ugawa, M. (2002) Contribution of endcrine-disrupting chemicals to estrogenicity of environmental water. J. Japan Soc. Water Environ., 25, 355-360.

2) Fukazawa, H., Hoshino, K., Shiozawa, T., Matsushita, H. and Terao, Y. (2001) Identification and quantification of chlorinated bisphenol $\mathrm{A}$ in wastewater from wastepaper recycling plants. Chemosphere, 44, 973-979.

3) Fukazawa, H., Watanabe, M., Shiraishi, F., Shiraishi, H., Shiozawa, T., Matsushita, H. and Terao, Y. (2002) Formation of chlorinated derivatives of bisphenol A in waste paper recycling plants and their estrogenic activities. J. Health Sci., 48, 242-249.

4) Nukaya, H., Yamashita, J., Tsuji, K., Terao, Y., Ohe, T., Sawanicshi, H., Katsuhara, T., Kiyokawa, K., Tezuka, M., Oguri, A., Sugimura, T. and
Wakabayashi, K. (1997) Isolation and chemicalstructural determination of a novel aromatic amine mutagen in water from the Nishitakase River in Kyoto. Chem. Res. Toxicol., 13, 1061-1066.

5) Rook, J. J. (1976) Chlorination reactions of fulvic acids in natural waters. Environ. Sci. Technol., 11, 478-482.

6) Kronberg, L., Christman, F. R., Singh, R. and Ball, M. L. (1991) Identification of oxidize and reduced forms of the strong bacterial mutagen (Z)-2-chloro3 -(dichloromethyl)-4-oxobutenoic acid (MX) in extracts of chlorine-treated water. Environ. Sci. Technol., 25, 99-104.

7) Nishikawa, J., Saito, K., Goto, J., Dakeyama, F., Matsuo, M. and Nishihara, T. (1999) New screening methods for chemicals with hormonal activities using interaction of nuclear hormone receptor with coactivator. Toxicol. Appl. Pharmacol., 154, 76-83.

8) Shiraishi, F., Shiraishi, H., Nishikawa, J., Nishihara, T. and Morita, M. (2000) Development of simple operational estrogenicity assay system using the yeast two-hybrid system. J. Environ. Chem., 10, 5764.

9) Hu, J., Cheng, J., Aizawa, T., Terao, Y. and Kunikane, S. (2003) Products of aqueous chlorination of $17 \beta$ estradiol and their estrogenic activities. Environ. Sci. Technol., 37, 5665-5670.

10) Baronti, C., Curini, R., D'ascenzo, G., Corcia, D. A., Gentili, A. and Samperi, R. (2000) Monitoring natural and synthetic estrogens at activated sludge sewage treatment plants and in a receiving river water. Environ. Sci. Technol., 34, 5059-5066.

11) Fukazawa, H., Matsushita, H. and Terao, Y. (1999) Formation of 2,4,6-tribromophenol in the night soil treatment plant (Japanese). J. Environ. Chem., 9, 931-937. 